\title{
Nation and Emotion: The Competition for Victimhood in Europe
}

\author{
Ulrich Schmid
}

Nations need narratives in order to constitute themselves. Homi Bhabha claimed in his seminal study Nation and Narration that nations are "systems of cultural signification" and that they promote "foundational fictions." National consciousness is based on a plot that allows for an identification of individuals with an "imagined community." Elements of such a narrative can be found in the preambles of constitutions, ${ }^{3}$ in political speeches, ${ }^{4}$ in canonized works of literature, ${ }^{5}$ and in popular culture such as folk songs ${ }^{6}$ or blockbuster movies. ${ }^{7}$ The outlook of these national narratives differs widely in time and space. Most often nations rely on a heroic epos as a basic narrative; a good case in point is the United States of America. The American national consciousness often invokes the foundation myth of the New World: a free individual has to fight for his own existence and ends his pursuit of happiness by creating a home. ${ }^{8}$ In the US context, the state and social concerns are secondary - what is most important is the self-attribution of US citizens to a nation of free, independent men who are responsible for their own fate. For a long time, this heroic narrative ${ }^{9}$ has served as a model for other nations in the world.

The late twentieth century, however, witnessed the rise of another master plot for the construction of a national identity: namely, victimization. Not victory but defeat, not heroic self-assertion but tragic self-abasement stands at the center of this variety of nation-building. Both heroism and victimization allow for the delineation of an in-group: the heroes are considerably stronger than their enemies, while the victims are considerably weaker than their enemies. Nevertheless, common suffering may tie a national community together with even stronger bonds than does common triumph. Suffering opens an ideological vacuum that needs to be filled with sense. Victory is replete with triumphal sense that needs to be dispersed - but this reservoir of ideology may be exhausted quite quickly. Suffering lasts longer than triumph, and it needs narrative support for its endurance.

Narratives of suffering and victimization have a special epistemological status: they are veridictions in the Foucauldian sense. The victim always claims to tell the truth - a truth that may not be challenged or questioned. If the veridiction of the victim were open for debate, the 
victim would lose his or her own identity. This is why the exemplary discourse of victimization, the Holocaust, does not tolerate comparisons and insists upon its uniqueness. ${ }^{10}$ The extermination of the European Jews is seen as a singular event - not so much regarding the number of victims, but regarding the evil intentions and the criminal energy of the perpetrators. Bearing witness to the Holocaust means establishing a truth that is then validated by its absolute cruelty. Any attempt to explain the behavior of the perpetrators psychologically would derogate from the narrative counter-power of the victim. The unconditional truth of the Holocaust endows the author of a narrative with absolute authority. This claim holds true for almost all discourses of victimization. Nations that build their identity basically on self-victimization do not allow for a new perspective or even a new assessment of their history of suffering. On the contrary, they even try to turn their own veridiction into jurisdictions by other nations. For instance, the Armenian genocide (1915) is officially recognized by the parliaments of Argentina, Belgium, Canada, Chile, Cyprus, France, Germany, Greece, Italy, Lithuania, Lebanon, the Netherlands, Poland, Russia, Slovakia, Sweden, Switzerland, Uruguay, Vatican City and Venezuela. In addition, the Ukrainian Holodomor (1932-1933) has been recognized as a genocide by the parliaments of Andorra, Argentina, Australia, Canada, Colombia, Ecuador, Slovakia and the United States. In both cases, pressure groups from the national elites lobbied heavily among the representatives of foreign parliaments in order to achieve their goal.

These endeavors show that truth is nothing without recognition. For the absolute claim of truth in a victimized nation, an acceptance of this narrative in public opinion is not enough. The veridiction of victimization demands institutional recognition; governmental acts, memorials, ceremonies, anniversaries and the like must guarantee both the importance and the validity of the national narrative.

Of course, there is a certain inflation of insistence on the truthfulness of a victimized discourse. The jurisdictions depend on the results of a parliamentary vote, and obviously such votes are not able to produce a truth, but only an opinion. Still, the added institutional prestige of all the parliaments that passed a bill of recognition strengthens the victimized nation's claim to truth. The veridictions also presuppose a kind of canonization of a certain historical discourse. Most national societies that are based on victimization have erected taboo zones around their historiography and public opinion. It is very hard to discuss or openly challenge victimizing narratives in such nations. In the following, I shall try to explore some cases in point and 
to analyze their specific use of victimization in their ongoing discursive project of nation-building.

\section{Israel}

Until recently, the Holocaust was the basic narrative for the raison d'être of the Jewish state. In the last twenty years, this exclusive position has been challenged from within and from without. In Israel, more and more voices are claiming that the state should emancipate itself from its Jewish history and identity and assume a more modern notion of citizenship that encompasses Palestinians as well. One of the most fervent critics of the concept of a "Jewish state," Avraham Burg, accuses Israel of "owning" the Holocaust and making political use of it."

Other authors go even further in their criticism of the role of the Holocaust. Roman Frister, himself a survivor of the Shoah, does not even deplore the destruction of the traditional Jewish habitat by the Nazi occupants:

Years afterward, when nothing was left of the Jewish shtetls of eastern Poland, their pathetic world would be remembered with sentimental longing for a lost culture. Their poverty, their filth, and their backwardness all forgotten, they would be honored for the charm of Peretz's stories, the legendary jokes of Hershele of Ostropolye, Chagall's airborne fiddler, the spiritual heritage of Hasidism. ${ }^{12}$

Criticism of the Holocaust-centered political culture in Israel may take various stances; there is also a more general critique of the political use that is being made of the Holocaust. In recent years, many authors and politicians have used the Holocaust as a generalized metaphor for genocide. This inflationary use has lessened the significance of the category: if genocide is everywhere, it is nowhere. The French philosopher Alain Finkielkraut maintains: "Used in contexts to which it does not apply, weakened by its metaphorical use, and degraded by needless repetition the term genocide is wearing out and dying. The exhaustion of meaning makes it easier for the workers for negation to do their job." ${ }^{\prime 3}$ Peter Novick interprets the Holocaust as a secondary conceptualization for the extermination of the Jews during World War Two, and stresses the meaning of the Six-Day War for the remembrance of the Holocaust: in 1967, it became palpable that the state of Israel was threatened existentially, and the memory of the Holocaust served as the main legitimizing discourse for the actions of the Israeli army. ${ }^{14}$ Norman 
Finkelstein goes a step further when he speaks about the "exploitation of Jewish suffering" in a veritable "Holocaust industry." He accuses pressure groups in the US of manipulating world public opinion in order to elevate Israel to the status of a victimized nation and to draw political advantage from this interpretation. ${ }^{15}$

This ongoing debate shows how victimization in the case of Israel is both crucial for the existence of the nation and subject to heavy criticism. At the beginning of the twenty-first century it has become clear that a great many other nations and interest groups have copied the Holocaust discourse, which they perceive as a success story for the establishment of a nation state in an adverse context.

\section{Poland}

Of all European nations, Poland probably has the longest tradition of a national consciousness that grew out of victimization. After the three partitions $(1772,1793$ and 1795) of the Polish-Lithuanian Commonwealth, the Polish state ceased to exist on the map of Europe for 123 years. In Polish culture, the three partitioning powers - the Russian Empire, the Kingdom of Prussia and Habsburg Austria - became synonymous with oppression and tyranny. Russia, in particular, was reproached for its ruthless brutality towards occupied Poland. The otherwise strong Polish Romantic nationalism was almost entirely built upon self-victimization. ${ }^{16}$ Poland was likened to Christ, who sacrificed himself for the redemption of mankind. Another metaphor used by the Polish Romantics was the Swiss mythical hero, Arnold Winkelried. At the Battle of Sempach in 1386, Winkelried allegedly opened a passage through the Austrian front line by throwing himself onto the enemy pikes. Both figures - Christ and Winkelried - are heroes and victims at the same time. The same holds true for Poland's construction of its own historical fate: Poland was defeated at the end of the eighteenth century, but with its own death, it allegedly saved Europe from the aggression of the barbaric East. Of course, this narrative downplays the fact that Prussia and Austria were equally responsible for the Polish partitions. The rhetoric of the heroic defeat is still very much present in the official national anthem. It harks back to a patriotic soldier's song from 1797 that puts the victory into the future tense: "Poland has not yet perished, / So long as we still live. / What the alien force has taken from us, / We shall retrieve with a sabre. We'll cross the Vistula and the Warta, / We shall be Polish. / Bonaparte has given us the example / Of how we should prevail." The expectation of a splendid victory became a 
leitmotiv in Polish political culture. Two uprisings in the nineteenth century (1830 and 1863), the Polish-Soviet war (1918-1920) and the beginning of World War Two in September 1939 were all interpreted as tragic events with the Poles as innocent sufferers and the foreign powers as vicious perpetrators.

Only one of these historical events had a happy outcome for Poland: the Polish-Soviet war ended with the unexpected victory of the Poles over the Red Army near Warsaw. Since this result did not fit the usual plot of victimization, it was readily termed the "wonder of the Vistula." Not only was the military result a miracle, but also first and foremost, the fact that for once it was not necessary to turn a defeat into a heroic deed. It is interesting, however, that the military victory of 1920 was not seen as an isolated event, but rather as a chapter in the Polish history of salvation. Even today, the Battle of Warsaw is presented not so much in terms of triumph, but in terms of suffering that is crowned by a military success. In 2010, Polish Television aired a melodramatic serial with the epic title 1920: War and Love, in which the country's military success is bought at the high price of personal tragedy. The same holds true for the monumental film The Battle of Warsaw by Jerzy Hoffmann, which came out in 2011.

Victimization in the Polish case often means the disempowerment of individual action. A victim is thereby not only subject to the actions of the perpetrator, but also plays a role in a mostly hidden master-plot. One of the most prominent events in Polish cultural history that reinforces the victimized version of national history is the massacre of around 4,40o Polish officers held captive at Katyn in 1940. Soviet historiography blamed the Nazis for the crime, and only in 1990 did Mikhail Gorbachev admit that the Red Army was responsible for this mass murder. In 1997 Andrzej Wajda made a film about Katyn, evoking, in the long final scene that shows the murder of the innocent and defenseless Polish victims, the shocking imagery of the Holocaust and Auschwitz. The political message of this kind of visualization amounts to the claim that the Poles also have their Holocaust - just with the crucial difference that Katyn is not sufficiently recognized abroad.

\section{Serbia}

On 28 June 1989, Slobodan Milošević gave an important speech at the site of the Battle of Kosovo. The celebration that day was centered on the 6ooth anniversary of the battle, which eventually ended with the defeat of the Serbian Kingdom at the hands of the Ottoman Empire. Contemporary Serbia is one of the nations that bases its foundational myth on a tale of defeat. The main argument of this myth is the readiness to fight - and, as in the Polish case, 
the defeat does not entail resignation, but resilience. The more destructive the defeat, the more decisive is the will to rise again. Milošević's speech is seen today as the starting point for the bloody wars in Yugoslavia of the 1990s.

Milošević, however, was not the creator of the Serbian victimization that eventually grew into a fervent and aggressive nationalism. Most important here was a memorandum by the Serbian Academy of Sciences and Arts from 1986, which interpreted the history of Serbia as an ongoing genocide against the Serbs. ${ }^{17}$ In this view, victimization served one main goal: it both entitled and empowered the victims to defend themselves.

The myth of Kosovo was elevated to a narrative of the promised land that had to be regained. This discursive argument did not even allow for a choice: the Serbs must fulfill a metahistorical mission and re-take the holy land of Kosovo into their possession. In the 1990s, the situation of the Serbs was repeatedly likened by Serbian intellectuals to the fate of the Jews: the Serbs had to suffer from Serbophobia, just as Jews had to endure anti-Semitism. The Serbs even had their own Holocaust during World War Two, the Croatian death camp Jasenovac being considered an Auschwitz for innocent Serbian victims. The estimate of victims at Jasenovac is very imprecise, the number of deaths ranging from 50,000 to over a million. Maintaining a high number of Serbian victims was crucial for the Serbian argument: if the number were to fall below 700,000, the Moslems and Croats murdered at the hands of Serbs at the end of the war would outnumber the Serbian victims, and thus put the basic narrative of Serbian victimization into question. ${ }^{18}$

The Serbian example shows how a tale of the constant, alleged humiliation of a great nation can be turned into an argument for war. In the Serbian narrative, the Serbian military actions in the former Yugoslavia were not aggressive, but a form of self-defense. In a way, the Serbian tragedy continues today. From a Serbian point of view, Europe still suffers from Serbophobia - and, unlike anti-Semitism, which has been banned from public discourse since the Holocaust, Serbophobia is a widely spread and even fashionable discourse that allows for the further exclusion of the Serbs from the economic, political and cultural benefits of the European Union.

\section{Ukraine}

Apart from a short period of national independence after World War One, Ukraine gained statehood only in 1991, and the newly founded state could not count on a homogenous national consciousness. In the West there was a strong Ukrainian movement, whereas the Donbas and the Crimea featured a 
mainly Russian ethnic and linguistic population; moreover, the Crimea had been part of the Russian Soviet Republic until 1953. Post-Soviet Ukraine for a long time had only one official language (Ukrainian), but since 2012 other languages (mainly Russian) have been acknowledged in specific regions as second state languages.

In this complex situation, it is clear that a national identity that should encompass the whole territory of Ukraine can hardly be built upon historical narratives. Ukraine is not only torn into two parts, a mainly Ukrainian-speaking West and a mainly Russian-speaking East, but is also fragmented into at least 22 regions with highly different traditions. ${ }^{19}$ Ukrainian citizens do not have a strong notion of a common descent; on the contrary, heterogeneity in culture and political attitudes prevails. In this situation, victimization can provide - or at least is more likely to provide - a common narrative for a Ukrainian national consciousness.

In Stalinist Ukraine, all ethnic groups and all social layers fell prey to repression, hunger and annihilation. Therefore victimization may provide an apt narrative for the precarious process of nation-building in postcommunist Ukraine. At the heart of this narrative lies the dreadful famine of 1932-1933 that claimed millions of victims in Ukraine and in Southern Russia. The first Western scholar to draw attention to this tragedy was Robert Conquest in his path-breaking book Harvest of Sorrow. ${ }^{20}$ In 1978 , the term Holodomor appeared in the Ukrainian émigré press, ${ }^{21}$ and ten years later it was prominently used by the writer Oleksa Musienko in an address to the writer's union in Kiev. ${ }^{22}$ Holodomor is a neologism that literally means killing by hunger; the assonance of the Ukrainian term for hunger (holod) with the first two syllables of Holocaust is an etymological coincidence, but of course also an intended connotation.

For the ukrainophile government of the Orange Revolution led by Viktor Yushchenko, the Holodomor was on top of the foreign policy agenda. Ukraine lobbied heavily abroad in order to get recognition for the interpretation that the Holodomor was perpetrated by the Russian elite in order to exterminate the Ukrainian nation. Historians and politicians pointed mainly to the correspondence between Stalin and Kaganovich, which was supposed to prove that the Holodomor was not just a consequence of the collectivization but also a genocide. In the foreground of the debate stood the 1948 UN convention, which defines genocide as "acts committed with intent to destroy, in whole or in part, a national, ethnical, racial or religious group." This notion of genocide was applied to the Ukrainian famine - with the explicit or tacit goal of establishing an emotional unity in Ukraine based on common victimization. 
There is a certain contradictory element in today's treatment of the Holodomor. On the one hand, the Holodomor serves as a homogenizing element for all victims of Stalinism on Ukrainian territory, regardless of their ethnic background. On the other hand, it is interpreted as a genocide perpetrated by Russians on Ukrainians. This would, however, exclude the numerous ethnic Russian victims from the narrative of victimization. Moreover, such an interpretation ignores the official Soviet ideology that was intended to destroy all traditional nationalities and to replace them with a Soviet patriotism that was based on a communist class identity. In 2010, Viktor Yanukovych, a declared Russophile, assumed the highest office in Ukraine. Under his presidency, the Holodomor was downgraded to a form of collateral damage of industrialization - corresponding to the official Russian view of the tragedy. On 17 May 2010, the Ukrainian and Russian presidents Yanukovych and Medvedev laid a wreath at the memorial of the Holodomor in Kiev, near the Saint Sophia cathedral. Shortly before this, the outgoing president Yushchenko had upgraded this memorial to a national site.

Western historians tend to accept the view that the Holodomor was a genocide; however, they point to several differences between the Holodomor and the Holocaust. The Holodomor did not aim at the extermination of a whole nation, it did not kill people directly and it was motivated politically rather than racially. ${ }^{23}$ This may be true, but the claim of collective victimization in Ukraine is obviously based on the model of the Holocaust.

\section{Russia}

Astonishingly enough, even Russia has - at least partially - adopted a discourse of victimization in the last few years. Triumph and victory continue to dominate, however, as the last functioning link in the weakening contract between the generations in Russia. Today, young people reproach their parents for quietism, for complete economic, social and political failure. The only remaining achievement of the Soviet generation (and in fact, in Russia there were three of them, as opposed to only one in Western Ukraine and Poland) is thus the victory over Nazi Germany. In the official historical discourse and in the minds of many older Soviet citizens, the Nazis were defeated mainly by the Red Army, and the death toll, at least, proves them right: during the war, the Soviet Union lost twenty million of its citizens, more than any other nation in the world. ${ }^{24}$

In a survey conducted in 1999, $84 \%$ of all Russians held that the victory over Nazi Germany was the most important historical event of the twentieth 
century; more important than the October Revolution, the Stalinist Terror or the dissolution of the Soviet Union. ${ }^{25}$

Central episodes of suffering, however, were singled out in Russian history. A case in point is the Leningrad blockade (1941-1943), which had horrible consequences, from starving to cannibalism. More than one million inhabitants lost their lives during the nine hundred days of siege. The official historiography claimed that these victims played an important role in the defense of the Soviet Union, and as early as 1 May 1945, Leningrad was awarded the title of a city-hero. The suffering of the population of Leningrad became one of the few topics for literary coverage that was exempted from official optimism. Otherwise, writers still had to adhere to the Socialist Realism that had been decreed for Soviet literature at the first conference of writers in 1934.

During the Soviet era, the Holocaust was a taboo. The main reason for the official silence was the official policy, which did not allow for a particularistic victimization. The communist discourse bemoaned the death of comrades, not of Jews or members of ethnic minorities who were deported systematically during World War Two. ${ }^{26} \mathrm{~A}$ good example of this strategy is the memorial site at Babi Yar, where in 1941 over 50,00o Jews from Kiev were shot. In 1976 a monument was erected commemorating the "Soviet citizens" who were murdered by the Nazis. It was only in 1991 that it became possible to mention the massacred Jews of Babi Yar explicitly in the inscription of a new monument.

The Soviet regime also feared the Holocaust for reasons of comparability with the Gulag. Ironically, there was a point of intersection between Eastern and Western discourses about the Holocaust: the Kremlin could have taken advantage of the Western imperative regarding the uniqueness of the Holocaust and thus rejected comparisons with Stalin's labor camps on these grounds. But this did not happen; there was too great a fear of a generalization of the Holocaust and an identification of the Soviet postwar system with a national-socialist dictatorship. Such precautions were not ill-founded: the leading Western interpretive concept for Soviet communism after World War Two was totalitarianism, which encompassed both Hitlerism and Stalinism. ${ }^{27}$

Since the breakdown of the communist system, Russia, the leading nation in the Soviet Union, has very much fostered the feeling of being the victim of a historical catastrophe. ${ }^{28}$ This holds particularly true for the relationship between Russia and the former Soviet republics. The Russians believe that they liberated the national republics from oppression and then provided them with funds and services in order to develop their own education, 
industry and governmental structures. From a Russian perspective, they have only received sheer ingratitude in return. This clash of historical interpretations has fed the feeling of victimhood among Russians: after all, they sacrificed themselves for the greater good, and the beneficiaries did not even take notice of their offering.

It is important to take this general background into account when issues such as the Holodomor are discussed in Russia. As a rule, Russian historians deny the categorization of the Ukrainian famine as a genocide and point to the similar suffering of the Russians during the Great Terror. In fact, the Russian ability to suffer is an important part of Russian cultural selfdescription. In a way, Russia is a double victim and has to endure a twofold hardship: it has suffered no less than other nations on Soviet territory, but in addition, it lacks recognition for its suffering.

\section{Germany}

For many decades after World War Two, Germany was the nation of perpetrators par excellence, and it is only in recent years that German suffering during the war has been addressed. There are basically three topics: the expulsion of the German population from the Eastern territories, the bombing of major German cities, and the raping of German women after the invasion of the Red Army. Each of these topics has generated massive interest in German mass culture: in 2001 the TV serial The Great Escape by Guido Knopp was aired, reaching an audience of five million viewers; in 2002 Jörg Friedrich published his book The Fire, which sold over 200,000 copies in hardback alone; and in 2003 the diary Anonymous in Berlin climbed the bestseller lists in Germany. ${ }^{29}$ Interestingly enough, each of these events triggered quite an ambivalent debate among the German public. Guido Knopp was reproached for having forged melodramatic clichés and an over-simplified interpretation of Nazi history; Jörg Friedrich was criticized for having emotionalized the bombing of Dresden; ${ }^{30}$ and the authenticity of the shocking account of Anonymous in Berlin was questioned. Others welcomed these narratives and saw them as the breaking of a taboo that had made German suffering during the war a non-subject. Today there seems to be a consensus among the German public that German narratives of victimization are legitimate as long as the German responsibility for the outbreak of World War Two and the Holocaust is accepted.

The German debate acquired a new dimension in 2006, however, when the Nobel Prize laureate Günter Grass confessed in his autobiography 
Peeling the Onion that he had belonged to the Waffen-SS as a young man. In 2002, Grass himself had engaged in the ongoing discussion about German suffering by publishing his novel Crabwalk about the vessel Wilhelm Gustloff, which was torpedoed by a Soviet submarine while evacuating German refugees from Eastern Prussia. The catastrophe led to over nine thousand causalities. After Grass's confession, this text could be read as a revisionist narrative about World War Two with an emphasis on German victimization. Even the wording of his confession made the membership in the SS appear more like an inflicted fate than a conscious choice.

The German case of victimization is unique, because this topic may not be touched upon without simultaneously raising fundamental questions. German suffering must always be weighed against German war crimes, since it is impossible to speak of the former and to remain silent about the latter.

\section{Conclusion}

At the beginning of the twenty-first century, a veritable rally of collective victimization can be observed. This hardly contestable phenomenon begs the question: what makes self-victimization the most prominent nation-building discourse at the beginning of the new century? One possible explanation points to the fact that we are not only in a postmodern, postnational and postheroic age, but also a post-historical one. Our sense of being part of history has weakened considerably since 1991, and at least in the Western world, there are no historical narratives left that would locate us in a temporal movement coming from somewhere and going to somewhere. If we do not know where we are in time, we need at least to know where we have been. Collective traumas can fulfill this task: we thus fill up our posthistorical void with posttraumatic emotions. National consciousness in the twenty-first century relies not so much on "imagined communities" as it does on incited and staged emotions that stem from collective victimization. The archetypal model for this discourse is, of course, the Holocaust. The imperative interpretation of the uniqueness of the Holocaust has not only been imposed by the victims, but also by the perpetrators. Today, there are only two public spheres in the world that do not allow for a comparison or a relativization of the Holocaust: Germany and Israel. Perhaps it is just this absolute claim to a victimized truth that makes the Holocaust a model for other nations that resort to victimization as a unifying discourse. Serbians have replaced their military fight with a discursive battle for the recognition of their suffering, Ukrainians even 
model the name of their national trauma on the Holocaust, the Poles refer to a tragedy in which innocent victims suffer an attack by an evil force, and the Germans maintain their respect for the Holocaust, but simultaneously establish a hitherto hidden narrative that points to the misery of human beings who bear no responsibility for the horrors of World War Two.

All the nations considered here play upon the strings of emotionality. Nationhood in the twenty-first century no longer relies on common dreams of hegemony or territorial expansion, as had been the case in the nineteenth or early twentieth centuries. Today, emotional nationhood is incorporated into enthralling narratives about honor, sacrifice and suffering.

\section{Notes}

1. Homi Bhabha, Nation and Narration (London: Routledge, 1990), 1-2.

2. Benedict Anderson, Imagined Communities: Reflections on the Origin and Spread of Nationalism (London: Verso, 2003).

3. Ulrich Schmid, "Constitution and Narrative: Peculiarities of Rhetoric and Genre in the Foundational Laws of the USSR and the Russian Federation," Studies in East European Thought 62:3-4 (2010), 431-51.

4. Thomas W. Benson, ed., American Rhetoric: Context and Criticism, with a foreword by Lewis Perry (Carbondale: Southern Illinois University Press, 1989).

5. Agnieszka B. Nance, Literary and Cultural Images of a Nation Without a State: The Case of Nineteenth-century Poland (New York: Peter Lang, 2008).

6. Tanja Popović, Die Mythologisierung des Alltags: kollektive Erinnerungen, Geschichtsbilder und Vergangenheitskultur in Serbien und Montenegro seit Mitte der 1980er Jahre, Basler Studien zur Kulturgeschichte Osteuropas, V (Zürich: Pano, 2003).

7. Robert B. Pippin, Hollywood Westerns and American Myth: The Importance of Howard Hawks and John Ford for Political Philosophy (New Haven: Yale University Press, 2010).

8. See the classic essay by Frederick Jackson Turner, "The Significance of the Frontier in American History" (1893), in The Frontier in American History (Mineola: Dover, 1996), 1-38.

9. Peter H. Gibbon, A Call to Heroism: Renewing America's Vision of Greatness, with a foreword by Peter J. Gomes (New York: Atlantic Monthly Press, 2002).

10. Jean-Michel Chaumont, La concurrence des victims: Génocide, identité, reconnaissance (Paris: La Découverte, 1997).

11. Avraham Burg, The Holocaust Is Over; We Must Rise from Its Ashes (New York: Palgrave Macmillan, 2008), 147.

12. Roman Frister, The Cap: The Price of a Life (New York: Grove, 1999), 175.

13. Alain Finkielkraut, The Future of a Negation: Reflections on the Question of Genocide (Lincoln: University of Nebraska Press, 1998), 95. 
14. Peter Novick, The Holocaust and Collective Memory (London: Bloomsbury, 2000).

15. Norman Finkelstein, The Holocaust Industry: Reflections on the Exploitation of Jewish Suffering (London: Verso, 2000).

16. Andrzej Walicki, Naród, nacjonalizm, patriotyzm (Kraków: TAiWPN Universitas, 2009).

17. Branimir Anzulovic, Heavenly Serbia: From Myth to Genocide (New York: New York University Press, 1999), 123.

18. David Bruce MacDonald, Balkan Holocausts? Serbian and Croatian Victimcentred Propaganda and the War in Yugoslavia (Manchester: Manchester University Press, 2002), 63-95, 165.

19. Yaroslav Hrytsak, "Dvadtsiat' dvi Ukraiiny," in Strasti za natsionalizmom, ed. Yaroslav Hrytsak (Kiev: Krytyka, 2004), 216-28.

20. Robert Conquest, The Harvest of Sorrow: Soviet Collectivization and the Terror-Famine (New York: Oxford University Press, 1986).

21. Vasyl Hryshko, Ukrains`kyj 'Holokost', 1933 (New York: Dobrus Suzhero, 1978).

22. O. H. Musienko, "Hromadians'ka pozycija literatury i perebudova," Literaturna Ukraina 18 February 1988, 7-8.

23. Andrea Graziosi, "The Soviet Famines and the Holodomor: Is a New Interpretation Possible, and What Would Its Consequences Be?," in Hunger by Design: The Great Ukrainian Famine and its Soviet Context, ed. Halyna Hrin (Cambridge: Ukrainian Research Institute of Harvard University, 2008), 1-13, here 12.

24. Bernd Bonwetsch, "Der 'Große Vaterländische Krieg:' Vom öffentlichen Schweigen unter Stalin zum Heldenkult unter Breschnew," in Wir sind die Herren dieses Landes, ed. Babette Quinkert (Hamburg: VSA, 2002), 173.

25. Lev Gudkov, ed., "Pobeda v vojne: K sotsiologii odnogo natsional'nogo simvola," in Negativnaja identichnost': Stat'i 1997-2002 gg (Moscow: Novoe Literatumoe Obozrenie, 2004), 20-58, here 21.

26. Terry Martin, "The Origins of Soviet Ethnic Cleansing," The Journal of Modern History, 70:4 (December 1998), 813-61.

27. Carl J. Friedrich and Zbigniew K. Brzezinski, Totalitarian Dictatorship and Autocracy (Cambridge: Harvard University Press, 1956).

28. Geoffrey Hosking, Rulers and Victims: The Russians in the Soviet Union (Cambridge: Harvard University Press, 2006), 392-95.

29. Helmut Schmitz, "The Return of Wartime Suffering in Contemporary German Memory Culture, Literature and Film," in A Nation of Victims?: Representations of German Wartime Suffering from 1945 to the Present, ed. Helmut Schmitz (Amsterdam: Rodopi, 2007), 1-30.

30. Bas von Benda-Beckmann, A German Catastrophe?: German Historians and the Allied Bombings, 1945-2010 (Amsterdam: Amsterdam University Press, 2010), 279. Lothar Kettensacker, Ein Volk von Opfern? Die neue Debatte um den Bombenkrieg (Berlin: Rowohlt 2003), 140-44. 


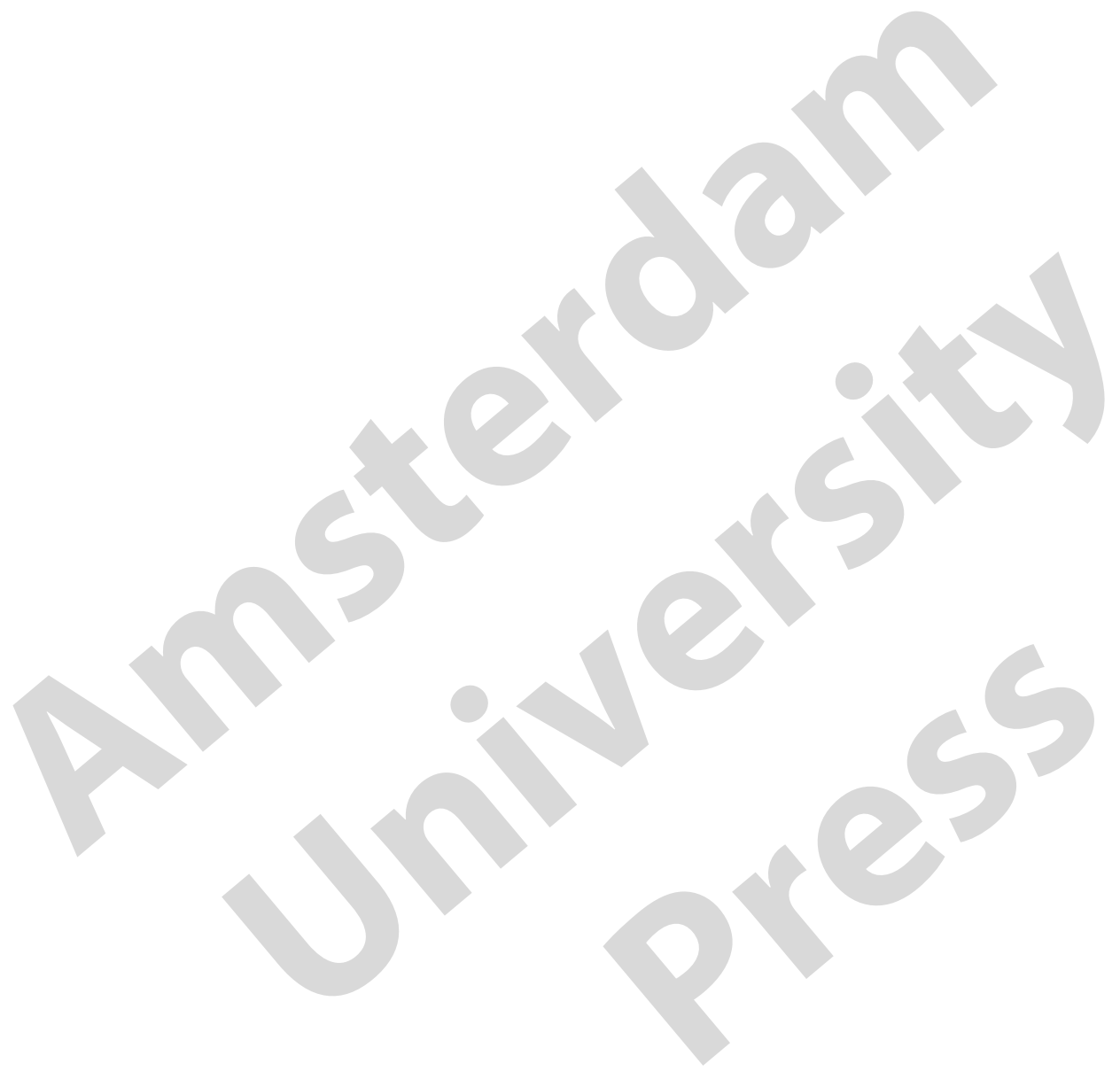

